\title{
Facilitating college teaching change: A model of inclusive deliberate teaching
}

\author{
Karla I. Loya \\ University of Hartford, USA
}

\begin{abstract}
Many college instructors begin their careers without knowing or using instructional best practices. During their careers, few will make drastic changes to their original teaching choices on their own. To respond to the needs and skills of increasingly diverse students, college instructors must not only improve their teaching practices, but also make them more inclusive. The study data comes from interviews about instructional vies and practices with 25 college faculty teaching undergraduate and graduate courses at an Eastern US university. This article first describes the mechanisms through which most teaching changes occur. Teaching changes can be typical or deliberate. Typical teaching changes usually encompass small modifications that suffice most needs but leave the instructor's teaching views and practices intact. Deliberate teaching changes are more intentional and drastic modifications that alter the instructor's views and practices of teaching. A model is presented next, to explain the mechanism through which college faculty can effectuate deep changes to their teaching to make it more inclusive. This model emphasizes the need for faculty to engage in reflection on their teaching to produce deliberate and inclusive teaching views and practices.
\end{abstract}

Keywords: University teaching; Instruction; Reflection; Inclusive teaching; Instructional change

Article History: Submitted 27 March 2021; Revised 1 July 2021; Published online 7 July 2021

\section{Introduction}

The teaching and learning process is perhaps the most important of the multiple activities occurring every day at universities and colleges around the world. The participants of this process, instructors and students, have been the subject of much research; consequently, there is abundant literature on college teaching and learning (Bain, 2004; Campbell et al., 2017; Filene, 2005). Yet, many college instructors continue teaching in outdated ways that have been documented to be ineffective (Evans \& Tress 2009; Lammers \& Murphy 2002; Zimmerman, 2020). Too often, college instructors begin teaching without a clear plan or training (Bain, 2004). Further, as colleges and universities enroll increasingly more diverse students' populations with distinct needs and skills, some instructors report facing difficulties engaging these new cadre of students in class (Almarghani \& Mijatovic, 2017). Despite the abundance of research on college instruction, scant

Address of Corresponding Author

Karla I. Loya, PhD, University of Hartford, 200 Bloomfield Ave., West Hartford, CT 06117, USA.

$\triangle 1$ loyasuare@hartford.edu

0000-0002-5073-5246

How to cite: Loya, K. I. (2021). Facilitating college teaching change: A model of inclusive deliberate teaching. Journal of Pedagogical Research, 5(3), 1-14. http:/ / doi.org/10.33902/JPR.2021370558 
work has examined the process through which teaching changes occur. Recent work is examining how inclusive instructional change happens (Magalhaes \& Hane, 2020). This article responds to this gap and presents a model of college teaching change as a mechanism that supports inclusive instructional approaches. This model can inform teaching practice for instructors and be used by instructional professional development providers to prompt reflective and inclusive teaching practices.

\subsection{Instructional Choices and Change}

There are several reasons for why newer, more inclusive instructional practices are not more predominant in colleges and universities, despite growing evidence of their effectiveness (Bain, 2004; Weimer, 2013). First, college teachers often report beginning to teach without knowing how to do it, and figuring it out as they go (Bain, 2004; Filene; 2005; Igwebuike et al., 2013). Second, lacking training, many novice college teachers tend to adopt the instructional approaches of their own teachers, without much consideration of how effective these practices might be (Oleson \& Hora, 2014; Strom et al., 2018). Third, eager to demonstrate content expertise, many novice college teachers choose content-driven instruction (Evans \& Tress, 2009; Lammers \& Murphy, 2002; Sirum et al., 2009). Thus, many college instructors begin teaching by adopting a traditional pedagogy.

Once teachers choose or adopt their pedagogies, they are unlikely to change them (Bain, 2004; Sirum et al., 2009). Change is even more challenging when faculty are not convinced of the value of spending time modifying their teaching methods (Sirum et al., 2009). Even with a move towards developing and promoting more innovative and inclusive pedagogies, traditional ones continue to be predominant in higher education, with lectures still being the primary delivery form (Evans \& Tress, 2009; Lammers \& Murphy, 2002; Sirum, et al., 2009). A recent multi-institutional study (Stains et al., 2018) reported after observing more than 2,000 science, math, and engineering college classrooms, that $55 \%$ of class time used conventional lecturing.

Teaching is a powerful tool. Traditional instruction is more likely than innovative pedagogies to foster and maintain teaching and learning environments that include and support only some forms of knowledge and only some knowers (Fricker, 2007). Through teaching, however, faculty can also create or transform the college learning environments to foster inclusive spaces where increasingly diverse students thrive and succeed (Clinton \& Higbee, 2011; Colbert, 2010; Loya, 2020).

Instructors' motivation to teach has been examined to explain why some faculties seem to care and do more about their teaching than others (Bain, 2004; Evans \& Tress, 2009; Oleson \& Hora, 2014). Evans and Tress (2009) concluded that faculty members were motivated to care about their teaching by self-esteem needs, which in turn were fed by beliefs of self-efficacy and the desire for a sense of achievement. That is, faculty members' self was an important part of their teaching. Similarly, Oleson and Hora (2014) reported that faculty members' past experiences shape their instructional choices.

But how exactly does teaching improvement happen in faculty members' teaching? For some instructors, time appears to be key in instructional change. Lattuca and Stark (2009) asserted that faculty members' teaching and learning views evolve over time, with more experienced teachers seeing their students as partners in learning, but they did not elaborate on how this change happens. Relationships with students appear to drive teaching change (Karpouza \& Emvalotis, 2019). Scant empirical work explains how teaching changes or expands over time, and what aspects of teaching tend to change. One of them is the study by Beyer et al. (2013), with 55 faculty members interviewed and surveyed on their process of making teaching changes. Confirming the literature, participants reported faculty-student interactions as the main reason for teaching changes. They also made teaching changes when seeking to increase their own or their students' learning or engagement, working on teaching values, reacting to maturity and growth changes, observing students' conduct or receiving feedback from them, interacting with peers, and needing to keep pace with content or technology changes. When faculty changed their teaching, they usually revised assignments, restructured classes, added active learning strategies, used 
technology, removed content, became more explicit, or added real-life examples (Beyer et al., 2013). This study advances the work of Beyer et al. (2013) and presents a model that explains instructional change, specifically towards more inclusive teaching and learning. The grounded theory model of inclusive teaching presented here highlights the individual nature of teaching change yet posits that faculty can and should be supported by the institutions and administration to engage in this process successfully.

\section{Method}

\subsection{Research Design}

This qualitative study employed an interpretivist grounded theory design (Charmaz, 2011; Corbin \& Strauss, 2008). Grounded theory focuses on understanding processes, their origin and development, and this study examined the process of teaching, particularly its shifts. Grounded theory provided both the rigor and flexibility needed to capture faculty members' perspectives and stories and link them to conceptual terms for analysis (Charmaz, 2011). Through a constant comparative process that begins during data collection, and continues through all data analysis and interpretation of the findings, grounded theory seeks to identify a shared story that explains the process or phenomenon under investigation, in this case, teaching changes and particularly inclusive teaching decisions. The research questions guiding this study were: How do faculty members make teaching changes? And in what ways do instructional changes lead to more inclusive teaching? The answers to these questions are addressed in this paper and presented as a model of teaching change.

\subsection{Site and Participants}

The study involved one academic department at a large, public research university in the Eastern U.S. The department was chosen for several reasons: First, it has four academic tracks, each with a distinct emphasis; second, the faculty came from varied professional backgrounds; third, all faculty taught and advised undergraduate and graduate students; and fourth, according to the department's website, both empirical scientific and social humanistic approaches to learning, teaching, and research were believed to be represented by the faculty. That is, the department represented the social sciences and had an emphasis in humanities (with required courses in social justice, gender, history, and politics, among others) while preserving a strong natural science focus (with courses in state-of-the-art technologies, image analysis, programming, and laboratory work). This department provided a setting with a variety of viewpoints, which were assumed to carry over into the teaching of the participating faculty.

All full-time faculty members in the department were invited to participate and the 25 who accepted the invitation were interviewed. As self-reported, 18 of the 25 were tenured or tenuretrack faculty, and 7 were non-tenure-track instructors or researchers with teaching loads. Twenty participants were men, 9 were foreign-born and -educated but only one self-reported as a faculty of color. Eleven participants also held administrative duties (including program and department appointments and directing research centers or labs). Participants' teaching experience ranged from 3 to 40 years (see Table 1).

\subsection{Data Collection and Analysis}

I conducted two one-hour in-depth, semi-structured interviews with each participant, for a total of more than 50 hours of interviews. Pursuing theoretical sampling, data obtained from one participant guided subsequent interviews to elaborate and refine emerging concepts until they were well defined (Charmaz, 2011). All participants were assigned pseudonyms and all data were deidentified prior to analysis. 


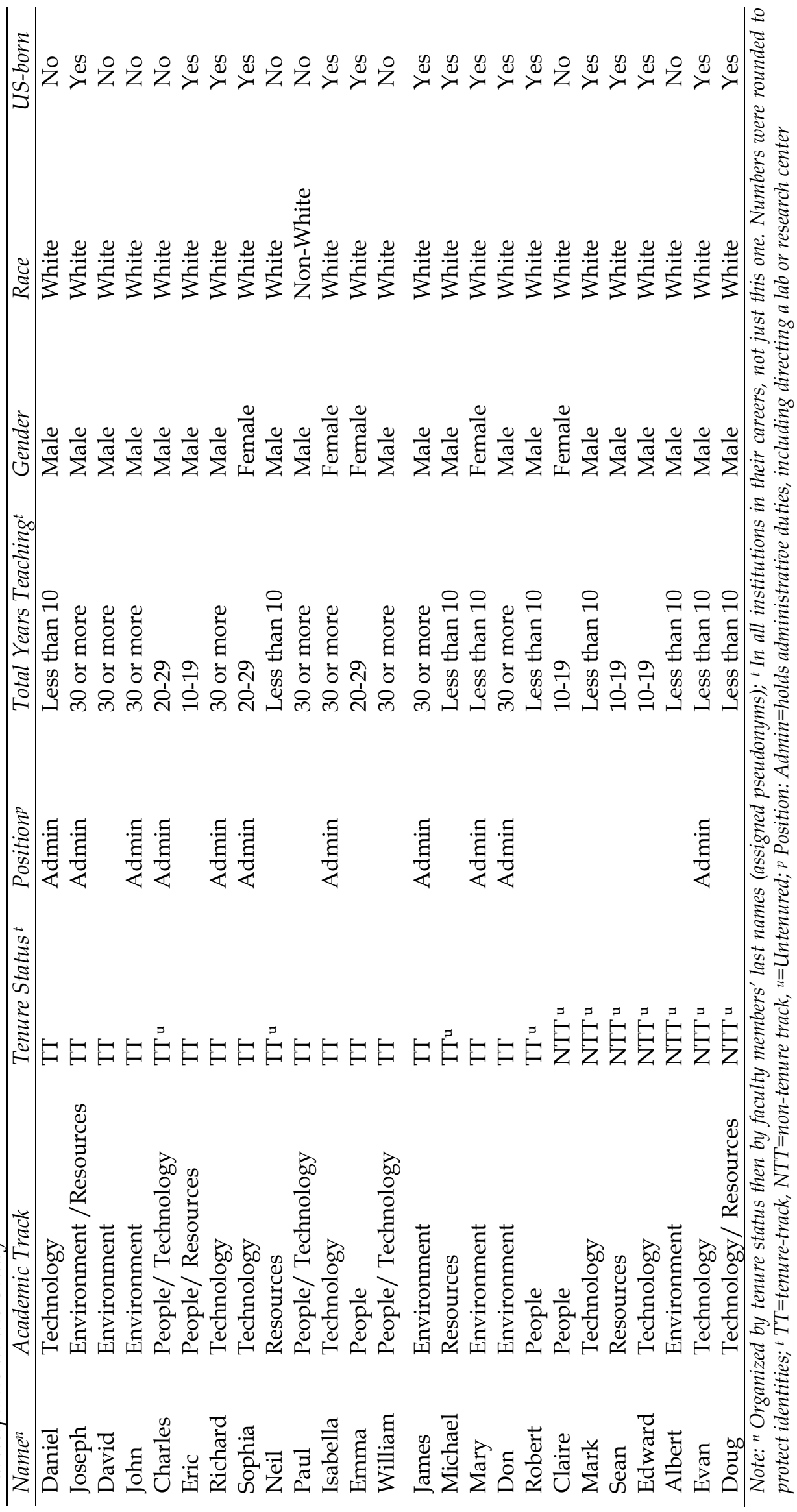


I followed interpretivist grounded theory data analysis procedures focusing on process, staying close to the data, and keeping codes simple and precise (Charmaz, 2011; Corbin \& Strauss, 2008). All data underwent several rounds of coding: Initial open coding to sort and separate data and identify gaps for further data collection; focused coding to revise and expand frequent and significant codes into concepts; axial coding to connect concepts and bring data back together; and theoretical coding to achieve theoretical saturation, with final categories and concepts well developed. I wrote analytic memos during data collection and analysis until a model of college teaching change emerged.

\subsection{Reflexivity and Trustworthiness}

This study, its design, data collection, analysis, and interpretation were likely imbued by my social identities and my personal and professional backgrounds. College teaching is a personal, instructional, and scholarly interest. As a Mexican-born Latina scholar in the United States, my gender, ethnicity, phenotype, and accent likely played a part in my interaction and rapport with participants, and on the ways in which I designed and conducted the study. To mitigate these effects and to bolster the study's trustworthiness, I adhered to grounded theory analytical protocols using a constant comparative analysis approach and using rich, thick description to let data guide the results. Further, I established respectful relationships with participants, acknowledged their stories and voices, and provided them de-identified summaries of preliminary models and findings for member-checking corroboration (Charmaz, 2011; Corbin \& Strauss, 2008). With these efforts I sought to enhance quality and to demonstrate that the findings are trustworthy and capture the participants' experiences.

\section{Findings}

This article is part of a larger study on college teaching, the origins of instructional practices, and teaching orientations (Loya, 2021). This article focuses on the emerging model of college teaching change with an emphasis on explaining the mechanism that leads to inclusive teaching. The process of instructional change involves the faculty's teaching views and practices, feedback and reflection, and decisions on instructional changes. When instructional changes are deliberate, they tend to inform the instructor's teaching views and practice, creating a recurrent cycle that creates possibilities for inclusive teaching.

\subsection{Teaching Views and Practices}

Teaching views reflect participants' beliefs about the roles and responsibilities of teacher and students, the purpose of content and of teaching, and whether power should be distributed and how. These components resemble what Weimer (2013) calls the key changes to teaching practice. Teaching views guide practices, not in the specific pedagogies and assessments an instructor chooses, but rather in the intentionality with which they implement pedagogies and assessments (see Figure 1). These teaching practices involve how content is delivered, how learning is ascertained, and who is involved in those decisions. Teaching practices in the classroom are recursive, shaped by and reshaping teaching views, in a constant loop. Together, teaching views and practices implicitly reflect faculty's epistemic beliefs, or teaching philosophies. That is, who can learn and produce knowledge and how (Alcoff, 2001). This in turn delineates who holds authority and responsibility in the teaching and learning environment. Teaching change can only be understood as intrinsically tied to how epistemic beliefs shape all instructional decisions.

Most faculty members tend to begin to teach guided by their first ideas about teaching, which frequently came from one or more of these sources: (1) individuals, including parents, spouses, and other individuals who are educators and teachers whom they respected, admired, and emulated, (2) early teaching experiences as camp counselors, tutors, or teaching assistants in graduate school, or (3) resources like training, textbooks, and syllabi from when they were students or from peers. Believed to be effective, these notions became borrowed ideas of teaching 
at the beginning of faculty teaching trajectories. In other words, these first borrowed views of teaching were also borrowed epistemic ideas.

Figure 1

Teaching Views and Practices

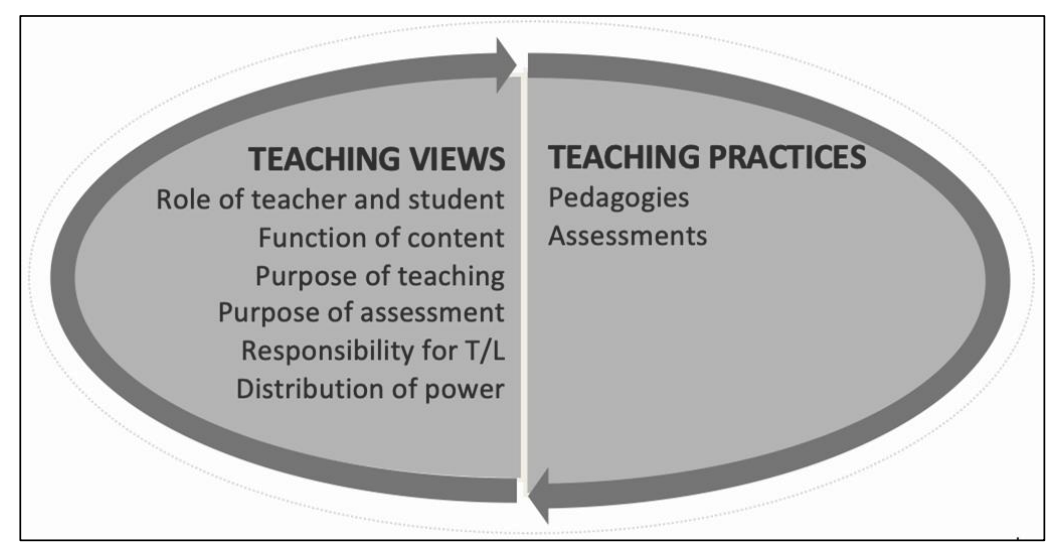

For some, deciding how to first teach felt like it was not even an option, as they lacked a sense of decision-making. Joseph explained: "Well, back then it was fairly standard, people simply lectured." Half of the participants have been teaching for at least three decades, hence this comment was not surprising. Isabella shared:

When I started to teach... that was 1976, yeah. It was the standard way of doing it, it was what they call the sage on the stage, where you just got up and talked for 50 minutes, that was just the standard way of doing it, and that's what I did.

Some faculty pointed out that they were received training during their doctoral studies to do research but lacked training on how to teach. Daniel said:

I find it amazing that everyone thinks that university professors have to be these excellent teachers, and I always wonder why [laughter]. How on earth does doing the research qualify for becoming an excellent teacher? I don't think that that's necessarily the case.

Others, like Sophia, mentioned teaching opportunities as graduate students:

I had given a few guest lectures and I had been a TA [teaching assistant] or taken those classes [that I was being asked to teach]. They weren't classes unfamiliar to me; they were design classes, so I had class notes [laughter]. I had a textbook, and I had been a TA in the main class [...]. I don't know, I was kind of just bemused, I guess. They wanted me to do it and I was, "Okay I'll do it and I'll figure out."

With time, most faculty face situations in which their original ideas and practices of teaching no longer function as expected. This awareness of something not quite working as usual prompts faculty to make changes. In this way, faculty begin creating their own teaching views and practices.

\subsection{Feedback and Reflection}

Participants described teaching as a process of constant self-appraisal of their teaching (Loya, 2021). Faculty reported constantly questioning their teaching. This questioning happened implicitly and explicitly, in and out of the classroom, at different points in a given course or semester, and across disciplines and teaching trajectories. It often involved instructors receiving feedback on their teaching from others or even themselves. Instances of instructors giving themselves instructional feedback include noticing when students were disengaged in a class, when very few students participated in class discussions, or when instructors were involved a deeper consideration at the end of a semester to evaluate a course. Don provided an example as he described his course planning and trying to gauge his teaching: 
I would decide what the students did in the labs and I got feedback on how that was going or not going. So, there was a continuous process of trying to stay informed on how the students were doing. Through that I could get a sense of what was working, what wasn't working. And some of that was me, some of it was the material, it was a combination of things. Some materials where just more conceptual and some students had more trouble with it; other material was not, and I find that still be the case.

Feedback on one's instruction often came from other sources as well. Different forms of information, like students' performance and feedback at the end of a class or semester, getting evidence of student learning, good students' grades, or even students' emails or chats during office hours helped participants confirm that their teaching was going well. Robert, a pre-tenured faculty, received feedback on his teaching from students in the end-of-the-semester course evaluations, and as a result decided to stop using an instructional technique, calling on student names for participation:

[The students] hated it, because it exposes them as people who are just hoping to passively take in this class, people who haven't done the reading, people who... It exposes all the things that they should expose, and they hated that. So, I had to drop it for the most part, because they really resented it, and I think that's a shame because I think it's a good tool, it produces good results, but I cannot force it on them without risking, you know... Most of the negative comments I've gotten since [I came to this university] have been associated with those cards, so I ended it after three weeks this semester.

When instructional feedback signaled to faculty that their teaching was lacking something or needed changes, faculty usually engaged in a process of reflection that led to decision-making. Two ways in which teaching changes occur are explained next.

\subsection{Typical and Deliberate Teaching Changes}

Teaching changes can occur in many different ways, but the process through which the decision to make instructional change happens can be explained as taking one of two forms. The first is more typical and requires small modifications that do not alter teaching views or practices and little or no improvement in instruction occurs. The goal is solely to solve what seems to be not working. This choice happens most often because it is easier, requires less time and effort, and small tweaks are usually sufficient to resolve what is not working. Eric exemplifies this typical way of making instructional adjustments:

There would be some days when I feel like I'm giving like a 20-30-minute lecture, and I can sense [the students] are really with me: They are asking questions, they are responding in such a way that I know that that information is being communicated. But sometimes [my lecturing] just doesn't work, and I have to try something different.

Eric added he would then improvise and post a photo or video to provoke students' reactions and engagement. Like other participants, Eric would often make changes in the moment, guided by information from the students in front of them. Similarly, Charles described his desire to avoid big instructional changes:

Also, you want to... if you find something that works, I don't think you necessarily want to change it. I probably experimented with things but not... there aren't huge changes; because I want to be able to teach a course... I want to be able to anticipate how it's going to go. I don't want surprises.

Small, typical instructional changes tend to satisfy most teaching needs and represent instructional changes made most often by most instructors, as tweaks often suffice to assure them that their teaching is functioning again, with small effort and cost involved. These typical changes are often in response to feedback on one's teaching that indicates that something is not quite functional, with or without reflection. The aim is to resolve an instructional difficulty, but it does not necessarily involve reflection of one's own teaching philosophy. 
The second way for teaching changes to occur requires more intentional and drastic modifications. Sometimes new information like feedback, or a new experience like attending a workshop or coteaching, challenges instructors' beliefs that their teaching is working, and these conflicts cannot be resolved with typical, minor changes, which might be attempted first. When facing an instructional difficulty, faculty are sometimes forced to look at their teaching views and practices, at their alignment, and whether or not these teaching views and practices need modifications to respond to the difficulty.

To reiterate, teaching views include the instructors' beliefs about the authority, roles, and responsibilities that students and instructors have in the teaching and learning process, as well as the purpose of content, power, and of teaching. These views inform and are informed by teaching practices, or the intentionality with which instructors deploy pedagogies and assessments to deliver content or assess learning, for instance. Teaching views and practices, combined, denote an instructor's epistemic beliefs. When instructors face an instructional difficulty that engages them in reflection of their teaching views and practices (i.e., epistemic reflection), the modifications needed to resolve the difficulty require that their teaching views and practices are modified as well. These resulting instructional changes are deliberate, because they occur with full awareness of the process and only as a result of careful thought (see Figure 2).

John provides an example of deliberate instructional change. John reported he had been teaching in Environmental Sciences for years in more or less the same way until he had the opportunity to coteach with Susan, a professor at the University's School of Education. Susan brought in Cody as her teaching assistant. The course was cross-listed for students who will become elementary school teachers, teaching science. John explained what happened one day in class:

We started talking about energy and asked what energy is, because that's the concept that we needed to start with; and you get back a definition that sounds like it came out of a high school physics class. And in my mind, I am just checking that off, "Okay, they got that. From now on I can use energy." Cody and Susan on the other hand are sitting there going, "Let's push this a little bit further." And after a while I begin to realize that [the students] don't understand anything about energy at all.

Figure 2

Process of Teaching Change

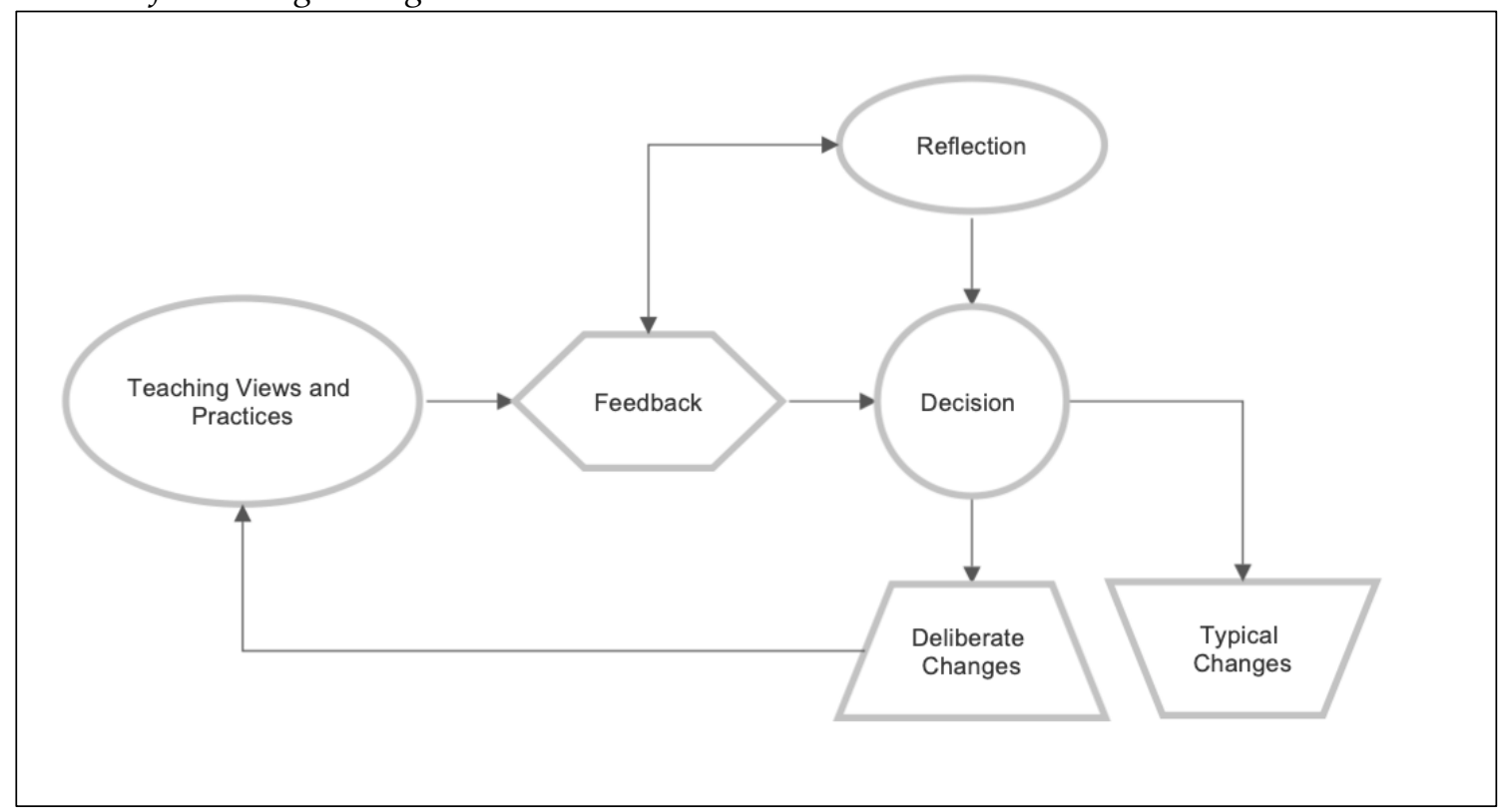


When students provided a factually correct answer, John assumed it meant they had understood the concept. But when Susan and Cody, who were trained in pedagogy, probed for understanding, it became apparent that the students were merely regurgitating memorized definitions but did not actually understand the phenomenon of energy. After this coteaching experience, John was now faced with the possibility that his teaching practices had been laden with unexamined assumptions. John continued:

And I realized that when I was teaching this course, which is the big Gen Ed class that I was teaching, that I would teach something and I would ask questions and get back the sort of response I was expecting, and just automatically assumed that they understood it.

As John reflected on this experience, he came to the realization that he needed to revise both his views and practices of teaching. His beliefs about his own and his students' roles and responsibilities (i.e., who asks, who answers) and his practice of questioning for fact retention no longer seem to align with his ideas of effective teaching. Witnessing his students not understanding a concept he assumed he had taught gave him pause. At this point, John entered into deeper reflection about this inconsistency:

I was sort of beginning to realize that when you do science and think about science, you just think in a different way to what a lot of the students are thinking but you don't realize it. So, I'm beginning to realize too that you need to spend far more time, unless you're happy with just the [students] knowing a lot of facts... if you actually want them to understand the process and the science involved, then you've got to cover a whole lot less than I do in my Gen Ed classes, and spend a lot more time in detail and approach it from multiple directions. Presenting it once in a way that seems logical to me didn't mean it was logical to the majority of people in the classroom.

In this description, John is reflecting on and articulating the new contradictions that he was facing as he questioned whether to continue teaching as he had taught before, or whether he needed to teach in a new way. He realizes that his views and practices of teaching have been unquestioned. As he sought deliberate instructional change, his role as teacher was no longer to merely ask questions and receive factual answers, but rather to probe for understanding before moving on. This new role influenced the amount and pace of content included in his courses ("you've got to cover a whole lot less") and the pedagogical approaches used, presenting material more than once, going slower ("in detail and approach[ing] it from multiple directions"). John's teaching views and practices became more attuned to his students, their learning needs and engagement: "Working with Susan and Cody completely changed the way I thought about things like general education." John's deliberate instructional changes occurred as he paused and reflected on his own instruction.

\subsection{Deliberate Teaching that is Inclusive}

Teaching changes that are deliberate involve altering instructors' views and practices. Together, these reflections and decisions lead to enhanced or improved instruction. In some cases, however, participants spoke of deeper ways of reflecting on their own teaching views and practices in ways that made inclusive teaching possible. Inclusive teaching is anchored on ideas of student diversity, social justice, equity and fairness, and assumes that instructors welcome and value difference (Loya, 2020). To fully include everyone in the classroom, epistemic credibility must be given to all participants. Epistemic credibility is used to designate who can receive knowledge or learn, and who produce knowledge or teach (Alcoff, 2001). In this case, it is the authority given by everyone in a learning environment to each member of the group, to be a learner and to be a contributing member in the production and transmission of knowledge (Loya, 2020). Participants whose instruction was inclusive spoke of extending their views and practices, from the roles and responsibilities assigned to both students and instructor, the importance given to content, the purpose of teaching and of power dynamics in the classroom; lastly, these expanded views 
influenced pedagogical choices. The process of making inclusive teaching changes is explained next (see Figure 3).

Many instructors, whether aware of it or not, tend to see their students only as learners and see themselves only as content experts whose task is to deliver that content to students. David exemplifies this view in the following quote:

Well, obviously I am the professor, and so I've got the experience, I've got the knowledge in the subject matter, and I am delivering that; I now know the best ways to try to transmit that information, but I don't view it as this kind of a thing, as me standing up there looking down on them. I view it as much more; I want feedback from them too. That's why I have questionand-answer session; and every question is legitimate, it really is. When people ask questions, I never put anybody down...

David first talks about the role of the teacher, who is not only expert and transmitter, but also solely responsible for teaching. David clearly holds the power in the classroom. Towards the end of the quote, he hints at wanting to expand that role and make the students more engaged in the process but does not fully grant them responsibility for it. Regardless of how many changes David makes to his teaching, it will not be inclusive until he changes how he views his learners. Conversely, Michael describes his students not only as learners but also as contributors in the shared production of knowledge; that is, in a more inclusive way:

Everybody has some experiences that they can bring to the table, everybody has education that they can bring to the table. All of them have different experiences and different education, so even the person that might be a junior in an undergraduate has things that they know that other students don't; and the older students have obviously things that other students don't. So I try to make an environment where the students can bring their own interests, their own ideas to the table...

Figure 3

Model of Inclusive Teaching Change

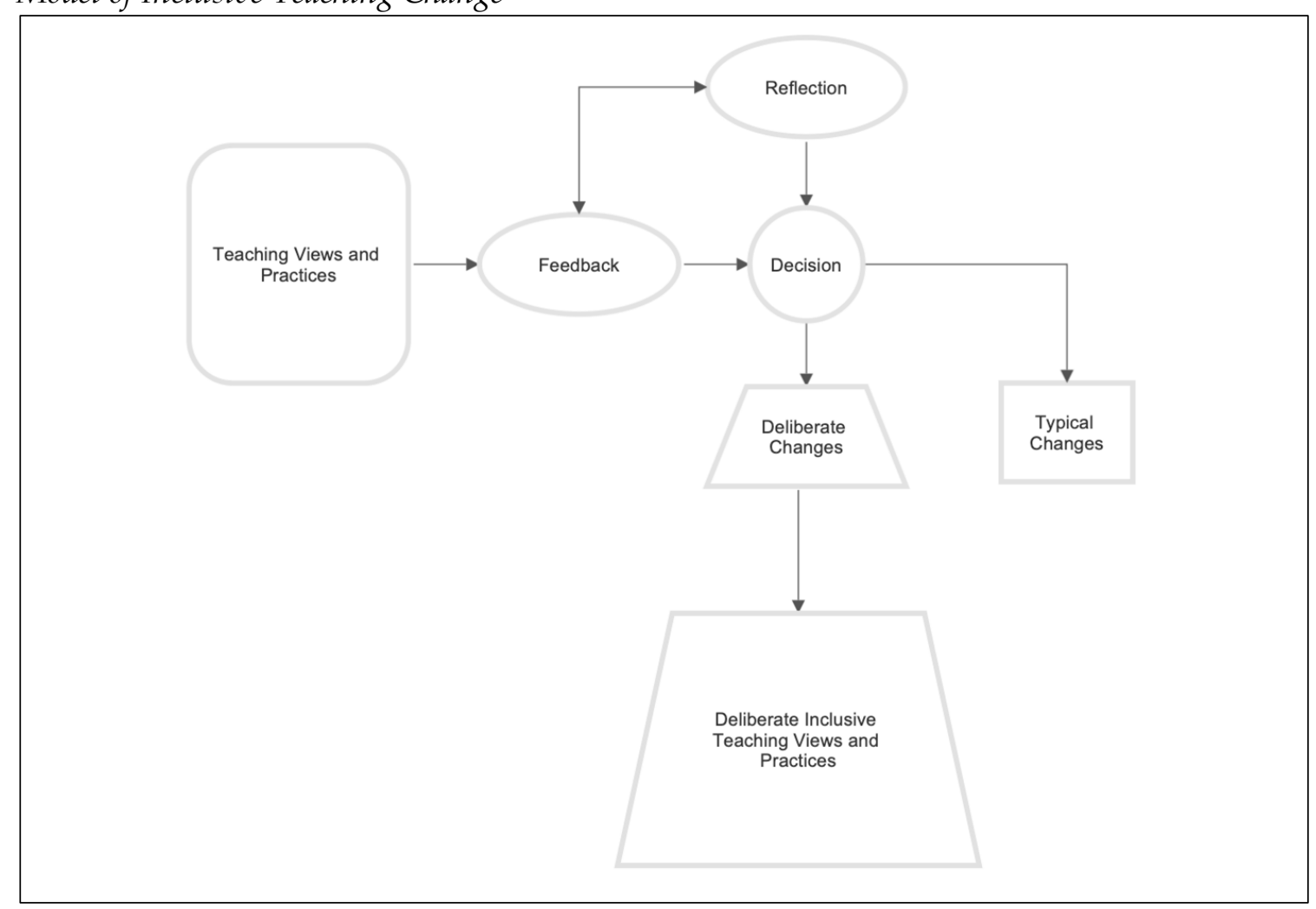

Similarly, John explained how teaching to students from different disciplines made him aware of the richness of perspectives in his classrooms, and to intentionally share the responsibility for teaching with them: 
I started teaching classes that came from multiple disciplines and would have a mix of firstyear, second-year, third-year [students], and then we started to really think about who was in the classroom and what they brought to it, and making more use of what they brought to the classroom, because now everybody was bringing something different. [...] Every student that came in, came with a different perspective and a different disciplinary background that let them add something to the conversation. In those classes the students become part of the teaching that's going on. [...] it is students teaching each other; there's a lot of peer learning happening.

When instructors see their learners as knowledge producers - and not only receivers - they are also more willing to let the teaching occur in different ways. And as instructors become more flexible, they often also begin to use varied and flexible pedagogies, to respond to students' needs, skills, and backgrounds. In this way of teaching there is less certainty about how learning happens, and it relies on careful curriculum and pedagogical design. The increasing flexibility means less control of what happens, which is purposely crafted. Teaching inclusively also means giving less attention to the content for its own sake, and it serves as a means for knowing (whether it is course or broader outcomes). As Emma said it, "it is okay to be behind." Emma said that this took her a long time to become comfortable with, "but if we are behind because we're having conversations, I am totally okay with that, and if we get through three quarters of the syllabus, I am okay with that also."

When describing his efforts to create possibilities for all students to participate and learn, Joseph also mentioned removing his previous emphasis on content:

I was trying to give students too much information, too fast, and expecting them to retain it; and I have learned that is more important to simplify, to give them multiple ways of accessing the information because some people learn well in what we call a traditional way, others learn better in nontraditional ways [...]. It's true, you cover less content, but I have asked myself, "Should I be playing to the few students who would get it all, or is it better for me to play it to the majority of the students and help them all understand it better, but maybe in less depth or probably more likely in less variety?"

In inclusive teaching, while power is still mainly held by the instructor, it is used to create respectful and welcoming learning environments where all or most students add their voices. As participants reflected on their instruction, some seemed comfortable when their teaching did not always work and saw mistakes as part of their own learning and improvement. For instance, Joseph explained how power dynamics have changed over time in his teaching:

In my early years as a teacher, I wasn't sufficiently sensitive to the students... I don't want to use the word force, but I forced the students to do things my way, and I didn't really pay much attention to their needs and differences and subtleties. Then as I became a more experienced teacher, I became more in tune with the students' needs and I became more willing to adapt the course to meet the students' needs. If I'm preparing a new course now ... I try to have my antenna up, so that I can be able to adjust the course so that it becomes a better learning experience..

Like Joseph, Emma was aware of the power dynamics in her classrooms. She described how she attempted to create more inclusive environments:

I try to give agency to students, both men and women, to be able to use the theories that we're working with, apply them in their own lives ... which gives them a little bit of power and agency to determine their own futures. By destabilizing power relationships in the classroom one of the things that I think it's very important... [...] I can't tell you how nuts I go when I am teaching a gender class that has 10 women and 2 men and the men are the people who are talking in the class. So, I have to figure out how to empower those women to feel comfortable in speaking and be able to say, "Okay, guys" and they are really great guys, I'm not saying that they are bad, but they've just been conditioned into this environment, where they feel very good about talking... 
Recognizing that many students expect to be passive receivers of information, Emma incorporated techniques to communicate expectations of student engagement and also create the spaces in her classrooms for this engagement to occur:

Usually what I do in the beginning of these smaller classes [is] ...Breaking them up into groups, so they report back, so you can slowly start building confidence, and next thing you know, it starts getting... You know, there's always going to be the male student and the female student who won't speak in class; they are uncomfortable with it. But that's something different than a dynamic that I see often in classrooms that we as instructors need to try to figure out.

Inclusive teachers constantly work towards creating environments that reflect a larger vision of teaching and learning: Inclusive instructors help students learn and encourage them to be knowledge creators and disseminators. This decentering of the teacher figure makes it possible for students to become responsible in the teaching and learning process; that is, students are given epistemic credibility to both learn and teach. Inclusive instructors acknowledge power dynamics in the classroom and aim to use their power to ensure that the learning environment is respectful and empowering. For Emma, this meant becoming comfortable with long pauses in her classes: "I am okay with those very long uncomfortable moments; it's taken me to be pretty senior to do that. [...]. I'm very comfortable to stand there and look at them. And I do that."

At the same time, inclusive teachers' vision of teaching and learning includes becoming learners, not only teachers. Emma saw herself as a learner: "I've been here [many] years. I am not being kind of coy by saying that I'm still learning, I really am still learning." Like Emma, Joseph spoke of his constant effort to reflect on his instruction and continue learning:

Every time I go into the classroom, and every time I go into another course, I am willing to try to be better than I was the previous time. And I think that that's helped my teaching because I never become complacent about it. So, I assume that I've improved over the years, but one never knows [laughter].

Inclusive instructors intentionally aim to decenter power dynamics in the classroom increase the number and kinds of voices and views that participate in knowledge production. By doing this, these teachers are contributing to the dismantling systems that maintain the status quo and to correcting potential injustice and inequity in the teaching and learning process. In other words, inclusive teachers create more inclusive classrooms and teaching practices.

\section{Discussion and Conclusion}

A model that explains the mechanism through which college faculty can effectuate deep changes to their teaching views and practices to make them more inclusive was presented here. By engaging in reflection and being responsive to feedback on their instruction, faculty members can engage in a process of decision-making that moves beyond typical or even deliberate teaching changes. Typical instructional changes do not alter significantly an instructor's views or practices of teaching. These changes are still pervasive at many college and university classrooms. Lack of time, training and other resources, and incentives (Beyer et al., 2013) might discourage faculty from investing the time and energy that deliberate and inclusive teaching requires. This is more likely at research-intensive institutions, where resources are allocated and rewarded based on research productivity (Evans \& Tress, 2009; Zimmerman, 2020). As one study participant said, "For all I care about teaching, it's only $40 \%$ of what I am supposed to be doing here; I got my own research, and my service to do. I am not going to reinvent..." While helpful and efficient, typical instructional changes alone are not sufficient to create inclusive teaching and learning spaces. The process through which more deliberate teaching changes occurs hints at the importance of allowing instructors the space and time for instructional reflection, so that teaching changes truly inform and reshape an instructor's views and practices of teaching.

The model of inclusive teaching change presented here is supported by extant literature and data from study participants. This model can inform the instructional development of faculty 
members and faculty development center administrators to emphasize the importance of teaching reflection and iterative modifications (Magalhaes \& Hane, 2020). The model is flexible enough to accommodate different needs, disciplines, approaches, and skills. As Beyer et al. (2013) indicate, "growth in teaching is a dynamic, iterative, complex, and challenging process. It is not linear, selfevident, or easy" (p. 132). The model of inclusive college teaching change aligns with liberatory instructional approaches that warn against one-size-fits-most views of teaching, and recognizes "each classroom as different, [where] strategies must constantly be changed, invented, reconceptualized to address each new teaching experience" (Hooks, 1994, pp. 10-11). Future research is suggested to address the study limitations, particularly applying this model to other academic settings, including other institutional types, different academic departments, and certainly other faculty members. Similar studies that include the perspectives of teachers with different genders, races, ethnicities, sexualities, religions, and abilities can support this line of research.

\section{References}

Alcoff, L. M. (2001). On judging epistemic credibility: Is social identity relevant? In N. Tuana \& S. Morgen (Eds.), Engendering rationalities (pp. 53-80). State University of New York Press.

Almarghani, E. M., \& Mijatovic, I. (2017). Factors affecting student engagement in HEIs - It is all about good teaching. Teaching in Higher Education, 22(8), 940-956. https:/ / doi.org/10.1080/13562517.2017.1319808

Bain, K. (2004). What the best college teachers do. Harvard University Press.

Beyer, C. H., Taylor, E., \& Gillmore, G. M. (2013). Inside the undergraduate teaching experience: The University of Washington's Growth in Faculty Teaching Study (2nd. ed.). State University of New York Press.

Campbell, C. M., Cabrera, A. F., Ostrow Michel, J., \& Patel, S. (2017). From comprehensive to singular: A latent class analysis of college teaching practices. Research in Higher Education, 58(6), 581-604. https:// doi.org/10.1007/s11162-016-9440-0

Charmaz, K. (2011). Constructing grounded theory: A practical guide through qualitative analysis. Sage Publications.

Clinton, L., \& Higbee, J. L. (2011). The invisible hand: The power of language in creating welcoming postsecondary learning experiences. Journal of College Teaching $\mathcal{E}$ Learning (TLC), 8(5), 11-16. https:// doi.org/10.19030/tlc.v8i5.4253

Colbert, P. J. (2010). Developing a culturally responsive classroom collaborative of faculty, students, and institution. Journal of College Teaching and Learning, 7(11), 15-24.

Corbin, J., \& Strauss, A. (2008). Basics of qualitative research: Techniques and procedures for developing grounded theory (3rd. ed.). SAGE Publications.

Evans, L., \& Tress, M. B. (2009). What drives research-focused university academics to want to teach effectively?: Examining achievement, self-efficacy and self-esteem. International Journal for the Scholarship of Teaching and Learning, 3(2), 1-17.

Filene, P. (2005). The joy of teaching: A practical guide for new college instructors. University of North Carolina Press.

Fricker, M. (2007). Epistemic injustice: Power and the ethics of knowing. Oxford University Press.

Hooks, B. (1994). Teaching to transgress: Education as the practice of freedom. Routledge.

Igwebuike, T. B., Okandeji, C. O., \& Ekwevugbe, A. O. (2013). Teacher educators' conception of teaching and learning in teacher education institutions. International Journal of Research Studies in Education, 2(2), 43-52. https:// doi.org/10.5861/ijrse.2012.96

Karpouza, E. \& Emvalotis, A. (2019). Exploring the teacher-student relationship in graduate education: A constructivist grounded theory. Teaching in Higher Education (24)2, 121-140. https:// doi.org/10.1080/13562517.2018.1468319

Lammers, W. J., \& Murphy, J. J. (2002). A profile of teaching techniques used in the university classroom. Active Learning in Higher Education, 3(1), 54-67. https:/ / doi.org/10.1177/1469787402003001005

Lattuca, L. R., \& Stark, J. S. (2009). Shaping the college curriculum: Academic plans in context. Jossey-Bass.

Loya, K. I. (2021). Toward deliberate college teaching: A constructivist grounded theory. College Teaching Journal. Advance online publication. https:// doi.org/10.1080/87567555.2021.1920880 
Loya, K. I. (2020). Creating inclusive college classrooms: Granting epistemic credibility to learners. In C. Osaki \& L. Parson (Eds.). Teaching \& Learning for Social Justice and Equity in Higher Education (Vol. I, pp117-135). Palgrave Macmillan.

Magalhaes, R. M., \& Hane, E. (2020). Building inclusive classroom practices: A curriculum for faculty learning communities based on metacognition. The Journal of Faculty Development, 34(3), 124-131.

Oleson, A., \& Hora, M. T. (2014). Teaching the way they were taught? Revisiting the sources of teaching knowledge and the role of prior experience in shaping faculty teaching practices. Higher Education, 68(1), 29-45. https://doi.org/10.1007/s10734-013-9678-9

Sirum, K. L., Madigan, D., \& Klionsky, D. J. (2009). Enabling a culture of change: A life science faculty learning community promotes scientific teaching. Journal of College Science Teaching, 38(3), 38-44.

Stains, M., Harshman, J., Barker, M. K., Chasteen, S. V., Cole, R., DeChenne-Peters, S. E., ... Young, A. M. (2018). Anatomy of STEM teaching in North American universities. Science, 359(6383), 1468-1470. https:/ / doi.org/10.1126/science.aap8892

Strom, K., Martin, A. D., \& Villegas, A. M. (2018). Clinging to the edge of chaos: The emergence of practice in the first-year of teaching. Teachers College Record, 120(7), 1-32.

Weimer, M. (2013). Learner-centered teaching: Five key changes to practice (2nd. ed.). Jossey-Bass.

Zimmerman, J. (2020). The amateur hour: A history of college teaching in America. Johns Hopkins University Press. 